http://vektor.iain-jember.ac.id

\title{
PENGGUNAAN STRATEGI PEMBELAJARAN INKUIRI TERBIMBING DALAM PEMBELAJARAN IPA DI PENDIDIKAN SEKOLAH DASAR
}

\author{
Firman Aulia Ramadhan ${ }^{1}$ \\ ${ }^{1}$ Program Studi Pendidikan Guru Madrasah Ibtidaiyah Universitas Islam Negeri Kiai Haji Achmad \\ Shiddiq, Jember, Indonesia
}

DOI : 10.35719/vektor.v2i2.35

\begin{abstract}
Abstrak. Penelitian ini bertujuan untuk mengetahui bagaimana penggunaan Strategi Pembelajaran Inkuiri Terbimbing pada Pembelajaran IPA di Pendidikan Sekolah Dasar.pada penelitian sebelumnya dengan membandingkan hasil inkuiri terbimbing dan inkuiri terstruktur, serta membandingkan penggunaan Strategi Pembelajaran inkuiri pada mata pelajaran IPA SD dan penerapan inkuiri pada mata pelajaran ilmu yang lain di sekolah dasar. Metode yang digunakan adalah metode deskriptif kualitatif. Hasil penelitian menunjukkan bahwa inkuiri terbimbing menunjukkan hasil yang signifikan terhadap hasil belajar siswa. Siswa lebih memahami pembelajaran dengan metode inkuiri dibandingkan dengan metode konvensional. Perbandingan hasil penelitian sebelumnya, menunjukkan penerapan metode inkuiri pada mata pelajaran jauh lebih baik dibandingkan mata pelajaran lainnya. Karena mata pelajaran IPA SD membutuhkan lebih banyak eksperimen dan latihan berdasarkan pengalaman pribadi
\end{abstract}

Kata Kunci: Inkuiri Terbimbing, IPA, Mata Pelajaran, Sekolah Dasar.

\begin{abstract}
This study aims to find out how the use of Guided Inquiry Learning Strategies for Science Learning in Elementary School Education others in elementary school. The method used is descriptive qualitative method. The results showed that guided inquiry showed significant results on student learning outcomes. Students better understand learning with the inquiry method compared to conventional methods. Comparison of the results of previous studies, shows the application of the method of inquiry to subjects is much better than other subjects. Because elementary science subjects require more experimentation and practice based on personal experience.
\end{abstract}

Keywords: Guided Inquiry, Science, Subjects, Elementary School

\section{PENDAHULUAN}

Di era globalisasi saat ini, segala aktivitas bergantung pada teknologi, begitu juga dalam bidang pendidikan. Perkembangan teknologi menghadapi Revolusi Industri 4.0 menuntut dunia pendidikan untuk terus berinovasi dalam meningkatkan kualitas sumber daya manusia di masa yang akan datang ${ }^{1}$.Dalam hal ini dunia pendidikan telah memberikan terobosan dalam rangka peningkatan kualitas sumber daya manusia. Terobosan tersebut merupakan kebijakan pemerintah tentang pembelajaran mandiri yang telah dicanangkan sejak awal tahun $2020^{2}$. Kebijakan yang membebaskan siswa untuk bereksplorasi dalam berpikir. Kebijakan yang juga menuntut guru berinovasi di era Revolusi Industri 4.0 untuk menyusun strategi pembelajaran yang tepat dan mencapai tujuan.

\footnotetext{
${ }^{1}$ Ghufron, G. "Revolusi Industri 4.0: Tantangan, Peluang, Dan Solusi Bagi Dunia Pendidikan". Seminar Nasional Dan Diskusi Panel Multidisiplin Hasil Penelitian Dan Pengabdian Kepada Masyarakat 2018, vol 1,no 1(2018),334 2 Ulun, A. G."Konsep 'Sabar' Di Merdeka Belajar Era New Normal" http://disdikkbb.org/news/konsep-sabar-dimerdeka-belajar- era-new-normal/2020/diakses tanggal 19-september-2021
} 
Semakin canggih teknologi maka pola pikir seseorang akan berubah. Demikian pula pola pendidikan dan pengajaran tidak dapat disamakan dengan pola pendidikan sebelumnya. Dengan kebijakan pemerintah tentang pembelajaran mandiri, diharapkan pola pendidikan lebih diarahkan pada pemanfaatan teknologi dan memberikan ruang bagi siswa untuk mengembangkan bakat dan kemampuan berpikir aktifnya. Pergerakan pola pendidikan yang dinamis juga menuntut guru untuk mengembangkan strategi pembelajaran yang dinamis pula. Terutama bagi siswa yang duduk di bangku sekolah dasar. Pada usia tersebut mereka menyukai sesuatu yang dinamis sehingga tidak mudah bosan.

Siswa sekolah dasar yang menyukai hal baru dan menemukan hal baru memberikan ide bagi guru untuk berinovasi dalam mengembangkan pembelajaran dengan memanfaatkan lingkungan sebagai sumber belajar ${ }^{3}$. Pembelajaran tidak harus terpaku pada modul yang berisi pertanyaan-pertanyaan sistematis tentang teori dan praktik ${ }^{4}$. Namun bisa juga dilakukan di luar kelas. Pemilihan strategi yang tepat memiliki pengaruh besar terhadap efektifitas proses pembelajaran sehingga tujuan pembelajaran dapat tercapai ${ }^{5}$. Pembelajaran IPA yang materinya masih abstrak memerlukan strategi yang tepat untuk mencapai tujuan pembelajaran.

IPA merupakan peluang besar yang strategis untuk menyiapkan sumber daya manusia dalam menghadapi era industrialisasi dan globalisasi. Pembelajaran IPA menanamkan kebiasaan pada diri seorang peserta didik untul berpikir dan berperilaku ilmiah yang kritis, kreatif, dan mandiri ${ }^{6}$. Disamping itu, menurut Permendiknas Nomor 22 Tahun 2006 pembelajaran IPA juga memiliki tujuan untuk memahami berbagai gejala alam yang ada disekitar kita, konsep, dan prinsip IPA yang bermanfaat serta dapat diterapkan dalam kehidupan sehari-hari, mengembangkan pemahaman dan kemampuan IPA, meningkatkan kesadaran untuk ikut serta dalam memelihara, menjaga, dan melestarikan lingkungan serta sumber daya alam yang ada, agar bumi kita tetap lestari.

Pembelajaran IPA mendorong peserta didik untuk menumbuhkan rasa ingin tahu dan melatih peserta didik untuk berpikir secara kritis dan objektif dalam memecahkan suatu permasalahan. Pembelajaran yang dapat dilakukan dengan percobaan akan memberikan pengalaman secara langsung bagi peserta didik sehingga menambah pemahaman mereka terhadap materi yang diajarkan. Hal ini dikarenakan mata pelajaran IPA termasuk ke dalam mata pelajaran yang dianggap sulit oleh peserta didik$^{7}$. (Annisa \& Simbolon, 2018) Salah satu faktor yang menyebabkan hal tersebut terjadi adalah pemilihan strategi dan metode yang kurang tepat dan kurang membekas pada ingatan peserta didik. Guru lebih sering menggunakan metode ceramah dan latihan soal saja sehingga menjadikan peserta didik tidak memiliki gambaran nyata dari suatu objek yang dijelaskan.

\footnotetext{
${ }^{3}$ kemdikbud."Peringkat dan Capaian PISA Indonesia Mengalami

Peningkatan".://www.kemdikbud.go.id/main/blog/2016/12/peringkat-dan-capaian-pisa- indonesia-mengalamipeningkatan/Desember-2016/diakses tanggal 19-september-2021

${ }^{4}$ Dewi, , Suyatna, A., Abdurrahman, A., \& Ertikanto, C.. "Efektivitas Modul dengan Model Inkuiri untuk Menumbuhkan Keterampilan Proses Sains Siswa pada Materi Kalor". Tadris: Jurnal Keguruan Dan Ilmu Tarbiyah, vol 2, no 2(Desember-2017), 105.

${ }^{5}$ Annisa, N \& Simbolon, N. "Pengembangan Media Pembelajaran Interaktif Ipa Berbasis Model Pembelajaran Guided Inquiry Pada Materi Gaya Di Kelas IV Sd Negeri 101776 Sampali". School Education Journal Pgsd Fip Unimed, vol 8,no 2,(2018) 222

${ }^{6}$ Handayani. "Pengaruh Model Pembelajaran Inkuiri Terbimbing Berbasis Lingkungan Terhadap Keterampilan Berpikir Kreatif Dan Penguasaan Konsep Ipa Kelas V Sd Gugus Viii Kecamatan Abang". Jurnal Pendidikan Dasar Ganesha, vol 5, no 1(Juni 2019), 128

7 Annisa, N \& Simbolon, N. "Pengembangan Media Pembelajaran Interaktif Ipa Berbasis Model Pembelajaran Guided Inquiry Pada Materi Gaya Di Kelas IV Sd Negeri 101776 Sampali". School Education Journal Pgsd Fip Unimed, vol 8,no 2,(2018) 229
} 
Setiap mata pelajaran yang ada, masing masing memiliki karakteristik yang berbeda-beda. Sehingga sangat dimungkinkan jika dalam satu mata pelajaran dengan mata pelajaran yang lain menggunakan strategi dan media pembelajaran yang digunakan secara berbeda. Salah satunya dalam mata pelajaran IPA. dimana mata pelajaran tersebut sangat efisien disampaikan dengan menggunakan sebuah strategi yang berdiskusi dan berkelompok. Dari sekian banyak strategi yang ada, Strategi Inkuiri sangatlah membantu penyampaian materi pelajaran IPA. Strategi Inkuiri berasal bahasa inggris inquiry yang berarti pertanyaan, pemeriksaan, dan penyelidikan. Inkuiri juga disebut juga sebagai suatu proses bertanya dan mencari jawaban pertanya secara ilmiah melalui penyusunan hipotesis hipotesis yang telah ditemukan terlebih dahulu ${ }^{8}$.

Berdasarkan permasalahan tersebut, strategi dan metode yang tepat dalam pembelajaran IPA adalah strategi inkuiri. Strategi inkuiri menganut aliran Piaget yang lebih banyak memberikan stimulus bagi peserta didik untuk menalar, menganalisis, dan menyimpulkan suatu hal. Piaget menjelaskan bahwa belajar ialah proses dari mental dan fikiran untuk mengoptimalkan semua potensi dalam diri setiap individu ${ }^{9}$, dengan demikian strategi inkuiri ini dirasa tepat dalam mengimplementasikan pembelajaran IPA pada siswa sekolah dasar. Dalam penelitian ini membahas inkuiri terbimbing pada pembelajaran IPA yang diterapkan pada siswa sekolah dasar.

Pembelajaran inkuiri terbimbing memfasilitasi peserta didik dalam proses membangun pengetahuan dan berusaha memotivasi peserta didik melalui penyelidikan dan penemuan. Keikutserataan peserta didik dalam proses belajar memungkinkan untuk mencari penyelesaian terhadap pertanyaan dan masalah- masalah yang dihadapi saat ingin membangun pengetahuan baru ${ }^{10}$. Ayat Al-Quran yang menerangkan tentang kegiatan pembelajaran berbasis inkuiri Yaitu Q.S. Al Mulk ayat 3-4,

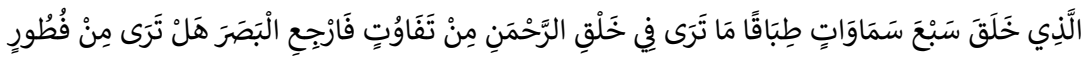

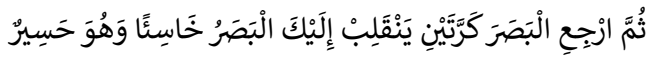

Artinya: Dialah yang menciptakan tujuh langit berlapis-lapis. Tidakkah kamu lihat sesuatu yang tidak seimbang pada ciptaan Tuhan Yang Maha Pengasih. Maka lihatlah sekali lagi, adakah kamu lihat sesuatu yang cacat. Kemudian ulangi pandangan (mu) sekali lagi (dan) sekali lagi, niscaya pandanganmu akan kembali kepadamu tanpa menemukan cacat dan ia (pandanganmu) dalam keadaan letih. (Q.S. al-Mulk [67]: 4-3)

Maksud dari ayat tersebut adalah kita sebagai manusia disuruh untuk melihat semua ciptaan Allah SWT. tidak hanya sekali lihat saja, tetapi berulang-ulang. Dimana semua ciptaan Allah tidak ada yang cacat, semuanya sempurna. Begitu pula dengan proses mempelajari sebuah ilmu, tidak boleh hanya mengkajinya sekali saja, tetapi harus berulang kali dikaji agar dapat memahaminya dan tertarik untuk terus ingin tahu.

\section{METODE}

Penelitian ini menggunakan metode analisis deskriptif kualitatif dengan menyajikan data secara analisis, gambaran, serta meringkas berbagai data. Teknik pengambilan data dilakukan dengan studi literatur yang melihat penelitian sebelumnya

\footnotetext{
${ }^{8}$ Nurfasiah."Pengaruh Model Pembelajaran Inkuiri Terbimbing". Jurnal Pena Ilmiah, vol 1, no 1, (juni 2016).7

${ }^{9}$ Lahadisi. "Inkuiri : Sebuah Strategi Menuju Pembelajaran Bermakna". Jurnal Al-Ta'dib, vol 7 no 2,(oktober 2014) 88

${ }^{10}$ Fisika, J. P., \& Pendidikan, U."Implementasi Model Pembelajaran Inkuiri Terbimbing untuk Meningkatkan Prestasi Belajar dan Kinerja IImiah". Vol 8 no 3(2014), 28
} 
dan mempelajari jurnal, skripsi, buku dan sumber bacaan lainnya yang dapat dijadikan sumber rujukan. ${ }^{11}$ Penguasaan materi dengan menggunakan strategi inkuiri yang didapat dari studi literatur adalah sebagai analisis data dalam penelitian ini. Hal tersebut dilakukan untuk mengetahui bagaimana implementasi startegi inkuiri terhadap peserta didik sekolah dasar dalam memahami materi mata pelajaran IPA.

\section{HASIL DAN PEMBAHASAN}

Pembelajaran inkuiri merupakan bagian terpenting dari pembelajaran berbasis kontekstual. Strategi pembelajaran inkuiri merupakan strategi yang menjadikan siswa sebagai pusat pembelajaran. Strategi ini melibatkan siswa untuk memaksimalkan kemampuannya dalam menganalisis, dan menyimpulkan sesuatu secara sistematis, kritis, dan logis. Strategi yang membutuhkan proses berpikir tingkat tinggi atau biasa disebut dengan High Order Thinking Skills (HOTS) ini menuntut guru untuk menerapkan metode inkuiri terbimbing dan inkuiri terstruktur dalam penerapannya di sekolah dasar. Karena dalam hal ini guru berperan sebagai fasilitator dan membimbing siswa dalam menentukan suatu masalah dan cara penyelesaiannya agar siswa dapat berkumpul dalam kelompok dan sesuai dengan kemampuannya.

Menurut Ansberry dan Morgan, inkuiri adalah suatu pendekatan pembelajaran yang mengeksplorasi, mengajukan pertanyaan, menyarankan ide, dan menemukan halhal baru untuk lebih memahami materi yang diajarkan ${ }^{12}$.Standar Nasional Pendidikan Sains mendefinisikan inkuiri sebagai kegiatan yang mengajak siswa untuk mengamati, bertanya, mencari referensi data yang diperoleh dari buku, jurnal, dan sumber referensi lainnya, mereview, mengolah data, menyajikan data, dan menjelaskan hasil dari hal-hal yang diamati. Pada hakikatnya pembelajaran yang mengajak siswa untuk menemukan pengetahuan, memahami, menganalisis, mengajukan pertanyaan, mengumpulkan data, dan menyimpulkan apa yang mereka amati.

Strategi inkuiri menjadikan siswa sebagai subjek pendidikan. Artinya, siswa berperan aktif dalam proses pembelajaran, sedangkan objek adalah materi atau hal-hal yang ditemukan sebagai bahan pembelajaran bagi siswa. Guru sebagai fasilitator dan motivator bagi siswa. Di tingkat sekolah dasar, guru memberikan arahan dan bimbingan yang lebih intensif kepada siswa dalam menerapkan strategi inkuiri.

Penelitian ini menggunakan metode inkuiri terbimbing. Inkuiri terbimbing dapat diartikan sebagai strategi bagi guru untuk memberikan petunjuk dan bimbingan mengenai materi yang diajarkan seperlunya. Instruksi yang diberikan oleh guru adalah untuk merangsang siswa untuk mencari dan menemukan informasi untuk dirinya sendiri dan memecahkan masalahnya sendiri. Tujuannya agar siswa mampu berpikir kritis, mampu memecahkan masalah, menguasai public speaking, dan dapat mengasah kemampuannya.Inkuiri terbimbing memiliki enam ciri, antara lain: (1) Siswa belajar berdasarkan pengalaman sehingga lebih aktif dan lebih kritis, (2) Siswa lebih memiliki sense of knowledge, (3) melalui petunjuk dan bimbingan guru.siswa dapat mengembangkan kelebihannya, (4) siswa berkembang secara bertahap, (5) perbedaan belajar yang ada pada siswa, dan (6) siswa mengenal lingkungan alam dan sosialnya. Dalam strategi inkuiri terbimbing ini guru berperan sebagai fasilitator yang berkonsentrasi pada siswa dalam memperoleh informasi, membantu siswa dalam menemukan konsep untuk penemuannya, mengasah bakat dan keterampilan siswa,

\footnotetext{
${ }^{11}$ Han."Metode Penelitian Kualitatif". Journal of Chemical Information and Modeling, vol 53,No 9,(oktober 2019). 1690

${ }^{12}$ Nurdyansyah \& Eni Fahriyarul Wahyuni. Inovasi Model Pmebelajaran Sesuai Kurikulum 2013.
} 
membantu siswa menemukan sesuatu yang baru sehingga pengalaman tersebut dapat digunakan. . tertanam dalam ingatan dan sulit untuk dilupakan, guru bukan satu-satunya sumber belajar, masih banyak sumber belajar lainnya ${ }^{13}$.

Metode pembelajaran inkuiri terbimbing lebih unggul dari model pembelajaran konvensional. Jika ditelaah secara teoritis, metode pembelajaran inkuiri terbimbing didasarkan pada teori pembelajaran yang menyarankan bahwa siswa harus belajar dengan berpartisipasi aktif dalam konsep dan prinsip yang telah ditentukan, sehingga mereka memperoleh pengalaman dan melakukan eksperimen yang akan membuka pikiran mereka untuk menemukan konsep dan prinsip. prinsip itu sendiri. Sebaliknya, pembelajaran konvensional lebih menekankan pada proses penyampaian materi secara lisan dari seorang guru kepada sekelompok siswa dengan maksud agar siswa dapat menguasai materi pelajaran secara optimal ${ }^{14}$.

Inkuiri terbimbing berbeda dengan inkuiri terstruktur. Structured Inquiry merupakan strategi inkuiri yang mengarahkan siswa untuk melakukan eksperimen dengan menganalisis secara sistematis, melakukan parameter, dan prosedur kerja ${ }^{15}$. Dalam inkuiri terstruktur, pertanyaan dan prosedur diperoleh dari guru, tetapi siswa dituntut untuk menemukan penjelasan berdasarkan bukti-bukti yang telah ditemukan ${ }^{16}$. Inkuiri terstruktur dapat dilakukan dengan berbagai kegiatan ilmiah.

Strategi inkuiri dapat diterapkan pada pembelajaran IPA sekolah dasar. Dengan melihat kesesuaian materi dan kelas yang diajarkan. Oleh karena itu, dalam penelitian ini strategi yang digunakan adalah inkuiri terbimbing dalam pembelajaran IPA dengan mata pelajaran pada siswa sekolah dasar. Metode pembelajaran inkuiri terbimbing dalam proses pembelajaran IPA dapat memberikan kesempatan kepada siswa untuk berpartisipasi dan aktif dalam proses pembelajaran. Untuk menemukan konsep yang akan dipelajari, siswa harus belajar dan mencari tahu sendiri, dengan memanfaatkan lingkungan yang ada sebagai sumber belajar. Keterlibatan siswa dalam memecahkan masalah dengan memanfaatkan lingkungan sebagai sumber belajar akan menimbulkan perasaan senang dan siswa akan lebih tertarik dan aktif dalam belajar. Siswa akan memiliki pengalaman dan pengetahuan yang baru dan lebih bermakna, dan apa yang dipelajari akan lebih tertanam kuat dalam benaknya. Dengan kuatnya informasi yang melekat pada ingatan siswa, tentunya juga akan berdampak pada perolehan hasil belajar siswa. ${ }^{17}$

Dalam penelitian yang dilakukan oleh Nana Hendracipta yang dilakukan pada siswa SD Ciherang, Gunungsari, Serang, Banten tahun 2017. Dengan populasi siswa kelas 5 sebanyak 26 anak dengan membagi siswa menjadi 2 kelompok yaitu kelompok eksperimen. kelompok. kelas dan kelas kontrol. dan dengan menggunakan mata pelajaran IPA sebagai alat tes menunjukkan hasil bahwa data untuk nilai rata-rata posttest siswa kelas eksperimen adalah 74,66 sedangkan kelas kontrol menunjukkan nilai 63,73 . Perhitungan yang digunakan dalam penelitian ini menggunakan data statistik inferensial untuk mengetahui prestasi akhir siswa dalam penerapan inkuiri terbimbing pada mata pelajaran IPA tentang sifat-sifat cahaya. Hasil akhir dapat disimpulkan bahwa

\footnotetext{
${ }^{13}$ Harnum. "Pembelajaran Inkuiri Terbimbing (Guided Inquiry) Dengan Peta Konsep Terhadap Hasil Belajar Pada Konsep Sistem Peredaran Darah". Institutional Repositories \& Scientific Journal, vol 3, no 2.(2016) 19-20

${ }^{14}$ Saniah, S., Hala \& Taiyeb. "Pengaruh Model Pembelajaran Inkuiri Terbimbing Terhadap Aktivitas , Motivasi Dan Hasil Belajar". Jurnal Bionature, vol 17, no 1 (maret 2017), 44.

${ }^{15}$ Mulyasa,Menjadi Guru Profesional.(Bandung,PT Remaja Rosda Karya,2006) 23

${ }^{16}$ Handriani,Harjono, A\& Doyan, A."Pengaruh Model Pembelajaran Inkuiri Terstruktur dengan Pendekatan Saintifik Terhadap Kemampuan Berpikir Kritis dan Hasil Belajar Fisika Siswa". Jurnal Pendidikan Fisika Dan Teknologi, Vol 1, No 3, 210

${ }^{17}$ Saniah. "Pengaruh Model Pembelajaran Inkuiri Terbimbing Terhadap Aktivitas, Motivasi Dan Hasil Belajar". Jurnal Bionature, vol 17, no 1,(Juni 2017) 45
} 
rata-rata hasil akhir kemampuan berpikir kritis siswa pada kelas eksperimen lebih baik daripada kelas kontrol. Hal ini dikarenakan penggunaan model inkuiri terbimbing dalam proses pembelajaran IPA sudah sesuai dengan pola pikir dan permasalahan sehari-hari siswa. Siswa di kelas eksperimen juga diuntungkan karena diberi kebebasan untuk menerapkan potensi dan potensi mentalnya secara maksimal sesuai dengan prinsipprinsip sains.

Studi lain dengan menggunakan strategi inkuiri dilakukan oleh Khoirul Arief.Strategi yang digunakan adalah inkuiri tingkat atau inkuiri berjenjang pada mata pelajaran IPA materi pemanasan global yang dilaksanakan selama tiga kali pertemuan dengan 35 siswa pada tahun 2015. Tingkat inkuiri yang dilakukan adalah discovery learning, demonstrasi interaktif, inkuiri. pembelajaran, dan laboratorium inkuiri yang bertujuan untuk mengetahui bagaimana siswa memahami dan meningkatkan literasi sains pada setiap jenjang yang diterapkan. Penelitian ini menggunakan sistem pretest dan sistem posttest sebagai alat uji hipotesis. Hipotesis dilakukan dengan menggunakan uji Wilcoxon yang menunjukkan hasil bahwa rata-rata hasil pretest siswa menunjukkan angka 7,94 sedangkan rata-rata hasil posttest mencapai 13,23. Sehingga dapat disimpulkan bahwa penerapan tingkat inkuiri sudah sesuai dengan harapan dimana skor posttest jauh lebih baik daripada skor pretest. Peningkatan literasi yang ditunjukkan siswa setelah penerapan level inkuiri juga menunjukkan hasil yang baik dengan perbedaan literasi siswa pada pretest dan posttest sebesar $20,33 \%$. ${ }^{18}$ Peningkatan literasi sains disebabkan oleh dorongan yang diberikan kepada siswa untuk membaca dan menjelaskan fenomena ilmiah atau disebut discovery learning. Kemudian, siswa melakukan penyelidikan terhadap penelitian yang dilakukan oleh guru, ini disebut demonstrasi interaktif. Tahap selanjutnya adalah siswa melakukan eksperimen ilmiah sesuai dengan apa yang telah mereka selidiki atau yang disebut pelajaran inkuiri. Tahap terakhir adalah penyelidikan laboratorium atau menafsirkan data dan bukti ilmiah dari hasil percobaan mereka. Tahapan tersebut memberikan pengalaman dan pemahaman kepada siswa, sehingga mereka lebih tertarik untuk membaca dan mengamati fenomena ilmiah.

Penerapan strategi inkuiri juga diteliti oleh Raden Gamal Tamrin Kumusumah di kelas IV SDN 28 Seluma tahun 2018, penelitian ini juga dilakukan pada mata pelajaran IPA namun dengan klasifikasi materi . satwa. Dalam penelitian ini dilakukan tiga tahapan yang disebut Pra-Siklus, Siklus I, dan Siklus II. Dalam setiap siklus dilakukan tes yang akan membandingkan hasilnya. Hasil akhir pembelajaran menunjukkan bahwa nilai siswa pada setiap siklus mengalami peningkatan. Pada tahap pra siklus nilai rata-rata siswa adalah 64,44, pada siklus I nilai rata-rata siswa adalah 76,11 , sedangkan pada siklus II nilai rata-rata siswa adalah 88,89 . Selisih peningkatan nilai siswa dari siklus I ke siklus II sebesar $11,67 \%$, dan selisih peningkatan dari siklus I ke siklus II sebesar $12,78 \%$. Nilai rata-rata siswa meningkat pada setiap siklusnya. Hal ini menunjukkan peningkatan yang signifikan dalam penerapan strategi inkuiri. ${ }^{19}$

Metode pembelajaran berbasis inkuiri ini tidak hanya dapat digunakan pada mata pelajaran IPA saja, tetapi pada mata pelajaran lainnya. Seperti, Matematika, IPS, dan PKN. Namun, tidak semua mata pelajaran dapat berhasil dengan baik dalam menerapkan metode pembelajaran inkuiri. Sebab, metode ini mendorong siswa untuk melakukan segala sesuatunya secara mandiri. Pada penelitian yang dilakukan oleh Nursamsiah di SDN 168432 Tebing Tinggi tahun 2017 dengan populasi 33 siswa kelas 3, hasilnya

\footnotetext{
${ }^{18}$ Khoirul Arief"Penerapan Levels of Inquiry Pada Pembelajaran Ipa Tema Pemanasan Global Untuk Meningkatkan Literasi Sains." Edusentris, vol 2,no 2, (desember 2015),166.

${ }^{19}$ Kusumah, Walid, Pitaloka,."Penerapan Metode Inquiry Sebagai Usaha Untuk Meningkatkan Hasil Belajar Ipa Pada Materi Penggolongan Hewan Di Kelas Iv Sd Seluma". Jurnal Pendidikan Matematika Dan IPA, vol 11, no 1, (2020). 142-153
} 
menunjukkan bahwa pada siklus II data klasikal diperoleh dari siswa, pada siklus I ketuntasan belajar siswa mencapai $78,78 \%$ atau 26 siswa berhasil. dari 33 siswa. Sedangkan pada siklus II, ketercapaian hasil belajar siswa menunjukkan angka $90,90 \%$ melebihi persentase ketuntasan yang diharapkan peneliti. Sehingga penggunaan metode inkuiri dalam proses pembelajaran mata pelajaran IPS dapat dikatakan berhasil. Karena, guru dapat mengarahkan siswa untuk bekerja sama dalam kelompok dan melaksanakan kegiatan pembelajaran sesuai dengan metode inkuiri, yaitu metode yang digunakan oleh seorang guru dalam materi ini. Siswa merumuskan hipotesis sesuai dengan masalah yang dibuat dalam rumusan masalah. Siswa aktif dalam diskusi dan bekerja sama dengan baik dalam kelompok untuk merumuskan hipotesis. dapat disimpulkan bahwa penerapan metode inkuiri dalam pembelajaran IPS dapat meningkatkan hasil belajar siswa. ${ }^{20}$

Penelitian metode inkuiri pada mata pelajaran selain IPA, dilakukan oleh Nopriani di SDN 60 Muara Bungo dengan menggunakan peserta didik yang duduk di kelas VI sebanyak 30 peserta didik sebagai populasi. Dalam penelitian tersebut dilakukan penelitian mengenai pengembangkan diri melalui metode inkuiri dari hasil tes dan wawancara kepada peserta didik menunjukkan hasil bahwa 16 peserta didik $(56,5 \%)$ menyukai pembelajaran dengan metode inkuiri karena sangat menarik dan cepat dipahami, sedangkan sebanyak 14 peserta didik $(43,5 \%)$ mengatakan bahwa pembelajaran dengan metode inkuiri sama saja dengan metode lainnya. Namun demikian, lebih dari $50 \%$ peserta didik menyukai dan merasakan hasil dari penerapan merode inkuiri ini. Sehingga pembelajaran PKn khususnya di Kelas VI dengan menggunakan teknik inkuiri dapat dikatakan efektif, sebab dapat mengembangkan beberapa sikap yaitu: sikap objektif, ingin tahu, terbuka, dan bertanggungjawab. Oleh karena itu, metode pembelajaran inkuiri ini lebih menekankan pada pencarian pengetahuan daripada perolehan pengetahuan. Dimana pada akhirnya akan membentuk pribadi yang baik dan peserta didik dapat mengaplikasikannya dalam kehidupan seharihari dengan cara membiasakan diri. Pembelajaran PKn dengan menggunakan metode inkuiri lebih efektif karena peserta didik dilibatkan secara aktif sehingga proses pembelajaran dapat menarik minat peserta didik. Dengan adanya bimbingan guru (proses tanya jawab) yang terus menerus dan saling berkaitan akhirnya peserta didik menemukan konsep akhir berupa kesimpulan dari hasil belajarnya, yaitu menahan diri dari perbuatan yang kurang baik yang dapat merugikan diri sendiri dan orang lain ${ }^{21}$.

Selain metode inkuiri terbimbing, metode inkuiri lainnya adalah metode inkuiri terstruktur. Dalam penelitian yang dilakukan Lia Saptini mengenai pengaruh pembelajaran inkuiri tersruktur di SMAN 1 Gerung menunjukkan hasil yang signifikan terhadap hasil belajar peserta didik sebab metode inkuiri dapat menambah keterampilan berpikir kritis peserta didik. ${ }^{22}$ Pada pembelajaran fisika, metode inkuiri terstruktur memberikan pengaruh yang cukup besar kepada peserta didik setingkat SMA.

Pada penelitian mengenai pengaruh pembelajaran inkuiri terstruktur dan model pembelajaran 5E (engange, explain, explore, elaboration, dan evaluate) atau tahaptahap pengorganisasian pada suatu proses pembelajaran pada mata pelajaran IPA yang dilakukan oleh Tri Asih Wahyu Hartati, menunjukkan hasil bahwa penerapan metode

\footnotetext{
${ }^{20}$ Nursamsiah. "Penerapan Inkuiri untuk Meningkatkan Hasil Belajar IPS Siswa Kelas III SD Negeri 168432 Tebing Tinggi."ESJ, vol 7, no 3 (desember 2017). 483

${ }^{21}$ Maslinda. "Penerapan Metode Inkuiri untuk Materi Pengembangan Diri (PKN) pada Siswa Kelas V SD Negeri 26 Manggalo Kecamatan Koto XI Tarusan". Jurnal Konseling Dan Pendidikan, vol 2,no 1,(Juni 2015). 58

22 Lia Saptini. "Pengaruh Model Pembelajaran Inkuiri Terstruktur dengan Pendekatan Saintifik Terhadap Kemampuan Berpikir Kritis dan Hasil Belajar Fisika Siswa." Jurnal Pendidikan Fisika Dan Teknologi, vol 1, no 3.(2015). 23
} 
inkuiri terstruktur tidak lebih baik daripada penerapan metode 5E. Sehingga penggunaan metode inkuiri terstruktur ini tidak memberikan hasil yang signifikan terhadap hasil belajar peserta didik ${ }^{23}$.

Namun, metode inkuiri terstruktur memiliki kelemahan yaitu metode ini mengharuskan adanya persiapan mental serta pembelajaran dengan metode ini kurang berhasil apabila dilakukan pada kelas-kelas dasar. Sehingga pembelajaran dengan metode inkuiri terbimbing ini tidak sesuai apabila diterapkan pada peserta didik setingkat sekolah dasar Selain inkuiri terstruktur, inkuiri terbimbing juga memiliki kelemahan yaitu memerlukan waktu yang cukup lama dalam mengimplementasikannya dan selama kriteria keberhasilan belajar peserta didik ditentukan oleh kemampuan penguasaan materi pelajaran. ${ }^{24}$ Tetapi, kelemahan dari metode ini dapat dikurangi dengan penerapannya secara berangsur-angsur. Meskipun memerlukan waktu yang relatif lama, kemampuan penguasaan materi peserta didik menjadi hal terpenting dalam sebuah pembelajaran. Sehingga sesuai apabila di implementasikan kepada peserta didik sekolah dasar.

Dari hasil penelitian sebelumnya tersebut dapat dilihat bahwa penggunaan strategi inkuiri terbimbing pada mata pelajaran IPA untuk siswa sekolah dasar yang diterapkan dengan tepat dapat menunjukkan hasil yang memuaskan. Terjadinya peningkatan nilai siswa serta peningkatan pemahaman literasi sains siswa menjadikan strategi tersebut sebagai salah satu strategi untuk mewujudkan merdeka belajar. Pemilihan strategi pembelajaran inkuiri terbimbing menjadi strategi pembelajaran yang paling tepat untuk pembelajaran IPA ${ }^{25}$. Menurut BSNP (Badan Standar Nasional Pendidikan) tahun 2004, menyatakan bahwa inkuiri merupakan proses membentuk suatu produk yang terintegrasi di dalam kelas. Inkuiri yang mengharuskan siswa untuk ikut aktif melibatkan diri terbukti mampu meningkatkan prestasi belajar, sikap, dan pemahaman siswa terhadap mata pelajaran IPA. Kegiatan belajar yang dilakukan oleh siswa secara langsung juga terbukti mampu menambah kemampuan berpikir kritis serta penerapan sikap-sikap ilmiah lainnya.

\section{KESIMPULAN}

Berdasarkan penelitian sebelumnya, penggunaan Strategi Pembelajaran inkuiri terbimbing berpengaruh signifikan terhadap hasil belajar siswa. Proses pembelajaran menunjukkan hasil yang sesuai dengan harapan dan tujuan pembelajaran. Inkuiri terbimbing juga menunjukkan hasil yang berbeda dengan inkuiri terstruktur, dimana inkuiri terstruktur lebih cocok untuk siswa sekolah dasar karena menekankan pada pengembangan diri yang masih memerlukan arahan dan bimbingan dari guru. Inkuiri terbimbing juga lebih cocok untuk mata pelajaran sains daripada mata pelajaran lainnya. Karena mata pelajaran IPA membutuhkan eksplorasi dan pemahaman yang lebih mandiri sesuai dengan praktik yang dilakukan siswa. Sehingga pembelajaran berbasis inkuiri dengan pembelajaran IPA dapat dilaksanakan dengan baik. Penelitian ini dapat dijadikan acuan bagi pembaca selanjutnya dan hendaknya mengambil yang baik dan menghilangkan segala kekurangan yang ada dalam penelitian ini. Peneliti dapat

\footnotetext{
${ }^{23}$ Hartati,, Corebima \& Suwono,. "Pengaruh Model Pembelajaran Inkuiri Terstruktur dan Siklus Belajar 5E Terhadap Keterampilan Proses Sains dan Hasil Belajar Kognitif Siswa pada Kemampuan Akademik Berbeda." Jurnal Pendidikan Sains (JPS), vol 3, no 1(Juni 2015), 26

${ }^{24}$ Anwar.Pengertian, Langkah-langkah, Kelebihan dan Kekurangan Metode Pembelajaran Inkuiri. https://anwarmath.blogspot.com/2015/01/pengertian-langkah-langkah kelebihan_21.html?m=1/Januari 2015/diakses tanggal 20 september 2021

${ }^{25}$ Nana Hendracipta"Perbedaan Kemampuan Berpikir Kritis Siswa Melalui Penerapan Model Inkuiri Terbimbing di Sekolah." JPSD, vol 53,no 9,(2017) 1692.
} 
mengetahui hasil penggunaan Strategi pembelajaran inkuiri terbimbing dalam pembelajaran IPA, dan dapat dijadikan bahan perbandingan dan masukan untuk penelitian sejenis

\section{DAFTAR PUSTAKA}

Annisa, N., \& Simbolon, N. (2018). Pengembangan Media Pembelajaran Interaktif Ipa Berbasis Model Pembelajaran Guided Inquiry Pada Materi Gaya Di Kelas IV Sd Negeri 101776 Sampali. School Education Journal Pgsd Fip Unimed, 8(2), 217-229. https://doi.org/10.24114/sejpgsd.v8i2.10199

Anwar. (2015). Pengertian, Langkah-langkah, Kelebihan dan Kekurangan Metode Pembelajaran Inkuiri. Retrieved from anwarmath.blogspot.com website: https://anwarmath.blogspot.com/2015/01/pengertian-langkah-langkahkelebihan_21.html?m=1

Baruga, D. D. I., \& Majene, K. A. B. (2016). Pengaruh Model Pembelajaran Inquiry Terbimbing Terintegrasi Ayat-Ayat Al- Qur' an Terhadap Minat Belajar Fisika Kelas X Ma Nurlina D.

Dewi, E. P., Suyatna, A., Abdurrahman, A., \& Ertikanto, C. (2017). Efektivitas Modul dengan Model Inkuiri untuk Menumbuhkan Keterampilan Proses Sains Siswa pada Materi Kalor. Tadris: Jurnal Keguruan Dan IImu Tarbiyah, 2(2), 105. https://doi.org/10.24042/tadris.v2i2.1901

Evi Nalisa, et al. (n.d.). Pengaruh Metode Inquiry Terstruktur Terhadap Hasil Belajar Murid Dalam Pembelajaran IPA. 2018, 1-10.

Fisika, J. P., \& Pendidikan, U. (2014). Implementasi Model Pembelajaran Inkuiri Terbimbing untuk Meningkatkan Prestasi Belajar dan Kinerja Ilmiah. 8(3), 25-41.

Ghufron, G. (2018). Revolusi Industri 4.0: Tantangan, Peluang, Dan Solusi Bagi Dunia Pendidikan. Seminar Nasional Dan Diskusi Panel Multidisiplin Hasil Penelitian Dan Pengabdian Kepada Masyarakat 2018, 1(1), 332-337.

Han, E. S. et al. (2019). Metode Penelitian Kualitatif. Journal of Chemical Information and Modeling, 53(9), 1689-1699.

Handayani, N. N. L. (2019). Pengaruh Model Pembelajaran Inkuiri Terbimbing Berbasis Lingkungan Terhadap Keterampilan Berpikir Kreatif Dan Penguasaan Konsep Ipa Kelas V Sd Gugus Viii Kecamatan Abang. Jurnal Pendidikan Dasar Ganesha, 5(1), 124383.

Handriani, L. S., Harjono, A., \& Doyan, A. (2017). Pengaruh Model Pembelajaran Inkuiri Terstruktur dengan Pendekatan Saintifik 
Terhadap Kemampuan Berpikir Kritis dan Hasil Belajar Fisika Siswa. Jurnal Pendidikan Fisika Dan Teknologi, 1(3), 210. https://doi.org/10.29303/jpft.v1i3.261

Harnum, Y. P. (2016). Pembelajaran Inkuiri Terbimbing (Guided Inquiry) Dengan Peta Konsep Terhadap Hasil Belajar Pada Konsep Sistem Peredaran Darah. Institutional Repositories \& Scientific Journal, 1650.

Hartati, T. A. W., Corebima, A. D., \& Suwono, H. (2015). Pengaruh Model Pembelajaran Inkuiri Terstruktur dan Siklus Belajar 5E Terhadap Keterampilan Proses Sains dan Hasil Belajar Kognitif Siswa pada Kemampuan Akademik Berbeda. Jurnal Pendidikan Sains (JPS), 3(1), 22-30.

kemdikbud. (2016). Peringkat dan Capaian PISA Indonesia Mengalami Peningkatan. Retrieved from kemdikbud.go.id website: https://www.kemdikbud.go.id/main/blog/2016/12/peringkat-dancapaian-pisa- indonesia-mengalami-peningkatan

Khoirul Arief, M. (2015). Penerapan Levels of Inquiry Pada Pembelajaran Ipa Tema Pemanasan Global Untuk Meningkatkan Literasi Sains. Edusentris, 2(2), 166. https://doi.org/10.17509/edusentris.v2i2.169

Kusumah, R. G. T., Walid, A., Pitaloka, S., Dewi, P. S., \& Agustriana, N. (2020). Penerapan Metode Inquiry Sebagai Usaha Untuk Meningkatkan Hasil Belajar Ipa Pada Materi Penggolongan Hewan Di Kelas Iv Sd Seluma. Jurnal Pendidikan Matematika Dan IPA, 11(1), 142-153. https://doi.org/10.26418/jpmipa.v11i1.34708

Lahadisi. (2014). Inkuiri: Sebuah Strategi Menuju Pembelajaran Bermakna. Jurnal Al-Ta'dib, 7(2), 85-98.

Lia Saptini. (2015). Pengaruh Model Pembelajaran Inkuiri Terstruktur dengan Pendekatan Saintifik Terhadap Kemampuan Berpikir Kritis dan Hasil Belajar Fisika Siswa. Jurnal Pendidikan Fisika Dan Teknologi, 1(3).

Maslinda. (2015). Penerapan Metode Inkuiri untuk Materi Pengembangan Diri (PKN) pada Siswa Kelas V SD Negeri 26 Manggalo Kecamatan Koto XI Tarusan. Jurnal Konseling Dan Pendidikan, 2(1), 55-61. Retrieved from http://jurnal.konselingindonesia.com/index.php/jkp/article/view/165 $/ 142$

Multisitus, S., Negeri, M. I., Sumbermanjing, D., Miftahul, M., \& Kabupaten, H. (2016). Implementasi Strategi Pembelajaran Inkuiri Terbimbing ( Guided Inquiry) pada PembelajaranIPA.

Mulyasa, E. (2005). Menjadi Guru Profesional. 10-40. 
Nana Hendracipta, et al. (2017). Perbedaan Kemampuan Berpikir Kritis Siswa Melalui Penerapan Model Inkuiri Terbimbing di Sekolah. JPSD, 53(9), 1689-1699.

Nurdyansyah, M. P., \& Eni Fahriyarul Wahyuni, M. P. . (2016). Inovasi Model Pmebelajaran Sesuai Kurikulum 2013.

Nurfasiah. (2016). Pengaruh Model Pembelajaran Inkuiri Terbimbing. Jurnal Pena Ilmiah, 1(1), 0-10.

Nursamsiah. (2017). Penerapan Inkuiri untuk Meningkatkan Hasil Belajar IPS Siswa Kelas III SD Negeri 168432 Tebing Tinggi.

Saniah, S., Hala, Y., \& Taiyeb, A. M. (2017). Pengaruh Model Pembelajaran Inkuiri Terbimbing Terhadap Aktivitas, Motivasi Dan Hasil Belajar. Jurnal Bionature, 17(1), 41-47.

Ulun, A. G. (2020). Konsep 'Sabar' Di Merdeka Belajar Era New Normal. Retrieved from disdikkbb.org website: http://disdikkbb.org/news/konsep-sabar-di-merdeka-belajar- eranew-normal/ 